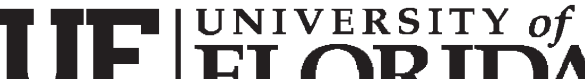 FLORIDA \\ IFAS Extension
}

\section{What Is Inquiry-Based Instruction? ${ }^{1}$}

\section{Anna J. Warner and Brian E. Myers ${ }^{2}$ \\ Introduction}

Educators should constantly evaluate and adjust their teaching approaches to meet the educational needs of their students and society. Federal, state, and local legislation has underscored the importance of developing students' abilities and performance in science, math, reading, and writing. Agricultural educators have the unique ability to incorporate all of these elements into their classrooms and teaching through the context of agriculture. Inquiry-based teaching methods allow teachers to expand students' science skills and help mold lifelong learners.

\section{What is Inquiry-Based Teaching?}

Inquiry-based teaching is a teaching method that combines the curiosity of students and the scientific method to enhance the development of critical thinking skills while learning science. As learners encounter problems they do not understand, they formulate questions, explore problems, observe, and apply new information in seeking a better understanding of the world. The natural process the learners follow when seeking answers and deeper understanding closely follows the generally accepted scientific method. Often, the answers proposed by learners lead to even more questions - much like the outcomes of research.

Students engage in five activities when they engage in inquiry learning and use the scientific method, as noted in the National Science Education Standards published by the National Academy of Sciences. Although these tasks occur in a logical progression, inquiry is a fluid process, and one task may lead back to a previous task. This process is illustrated in Figure 1.

According to the National Academy of Sciences (1995), when students learn through inquiry, they:

1. question;

2. investigate;

3. use evidence to describe, explain, and predict;

4. connect evidence to knowledge; and

5. share findings.

Each of these factors can be found in the following example.

1. This document is AEC394, one of a series of the Department of Agricultural Education and Communication, Florida Cooperative Extension Service, Institute of Food and Agricultural Sciences, University of Florida. Original publication date: September 2008. Visit the EDIS Web site at http://edis.ifas.ufl.edu.

2. Anna J. Warner, graduate student, and Brian E. Myers, assistant professor, Department of Agricultural Education and Communication, Institute of Food and Agricultural Sciences, University of Florida, Gainesville, FL 31611.

The Institute of Food and Agricultural Sciences (IFAS) is an Equal Opportunity Institution authorized to provide research, educational information and other services only to individuals and institutions that function with non-discrimination with respect to race, creed, color, religion, age, disability, sex, sexual orientation, marital status, national origin, political opinions or affiliations. U.S. Department of Agriculture, Cooperative Extension Service, University of Florida, IFAS, Florida A. \& M. University Cooperative Extension Program, and Boards of County Commissioners Cooperating. Larry Arrington, Dean 


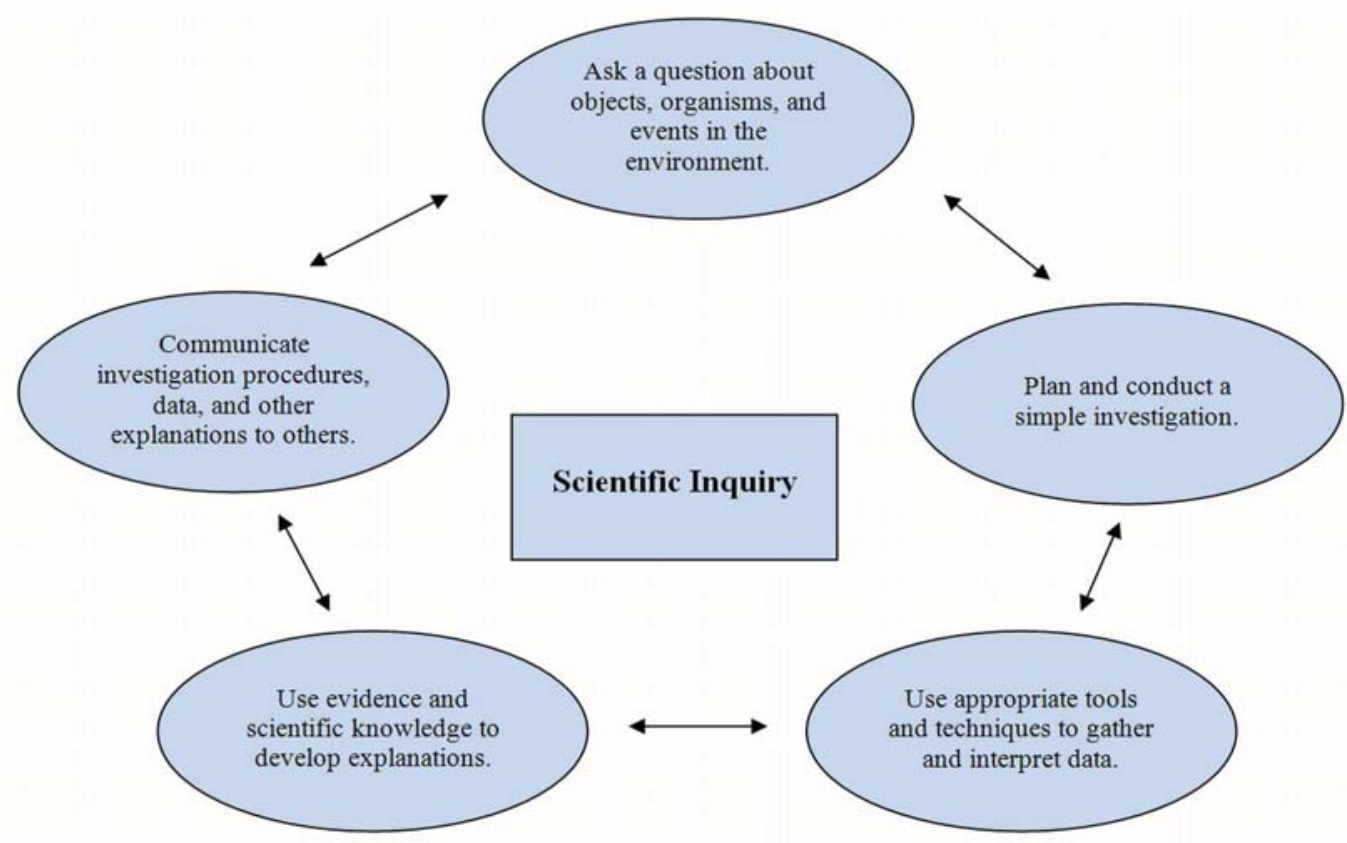

Figure 1. Tasks of Inquiry Credits: Carin, Bass, \& Contant, 2005, p. 21

Example 1

\section{Example}

\section{Step 1: Question}

Students in an introductory agricultural education course notice that one of the two plants the class planted on the same day and placed in different parts of the classroom is bigger than the other. This observation may cause the students to ask, "What is making Plant A grow faster than Plant B?".

\section{Step 2: Investigate}

Students know plants need water to grow. They know the plants receive the same amount of water because they are responsible for watering the plants and give the same amount of water to each plant. Since the students know the water is the same for each plant, they decide there must be another explanation for the difference in plant growth. The students research plant growth and find light and temperature are also important factors. The students decide to monitor the temperature in each location to see if a temperature difference exists. For one week, the students take the temperature next to each plant in the morning and the afternoon.
Step 3: Use Evidence to Describe, Explain, and Predict

At the end of the week, the students review all of the data collected and determine the temperature is the same in both locations. Their findings eliminate temperature as the cause of Plant A growing faster than Plant B. The learners predict that light is the cause of the difference in plant growth, so they decide to monitor the amount of light the plants are receiving.

\section{Step 2: Investigate}

The students decide to count the hours of sunlight each plant receives in one day. Every hour, the students check each plant and mark if the plant is in the sun or not.

\section{Step 3: Use Evidence to Describe, Explain, and}

\section{Predict}

At the conclusion of the experiment, the students find Plant A receives four hours more sunlight than Plant B. They can conclude light affected the different growth rates of the two plants.

\section{Step 4: Connecting Evidence to Knowledge}


As a result of their experiment, the students note that water, temperature, and light affect plant growth. They realize a difference in one of these factors can cause a noticeable difference in plant growth.

\section{Step 5: Sharing Findings}

Since the students did such a good job finding the answer to their question, the teacher asks them to share their work during a parent showcase night. The students explain each aspect of their experiment process and discuss the findings and conclusions.

\section{Why Use Inquiry-Based Teaching?}

Agricultural educators can play a vital role in achieving some of the standards in science, math, reading, and writing, while teaching the agricultural curriculum. When students engage in inquiry, they utilize skills from across multiple disciplines (e.g., science, math, social science, language arts, and creative thinking) by collaborating with others, collecting and interpreting data, organizing and developing representations of their data, and sharing their findings with others. Inquiry-based teaching methods provide flexibility to the teachers and students by facilitating student contribution of their strengths, so students of different developmental levels and learning styles learn together. Inquiry-based methods align with the hands-on, experiential education format agricultural education provides. Inquiry-based learning requires students to actively use their hands and minds, and as a result, students are able to assemble ideas to create their own knowledge and understanding.

\section{Conclusion}

Inquiry-based methods support many national and state learning standards and allow agricultural educators to contribute to school-wide educational goals. For additional ideas on further developing inquiry-based learning techniques, see the companion publication titled Implementing Inquiry Based Teaching Methods.

\section{Useful Resources:}

Budnitz, N. (2000). What do we mean by inquiry. Retrieved January 21, 2008, from http://www.biology.duke.edu/cibl/inquiry/

what_is_inquiry.htm

Carin, A. A., Bass, J. E., \& Contant, T. L. (2005). Methods for teaching science as inquiry (9th ed.). Upper Saddle River, NJ: Pearson Prentice Hall.

Hebrank, M. (2000, August). Why inquiry-based teaching and learning in the middle school science classroom? Retrieved January 21, 2008, from http://www.biology.duke.edu/cibl/inquiry/ why_inquiry_in_ms.htm

Llewellyn, D. (2002). Inquire within: Implementing inquiry-based science standards. Thousand Oaks, CA: Corwin Press.

Llewellyn, D. (2005). Teaching high school science through inquiry: A case study approach. Thousand Oaks, CA: Corwin Press.

National Committee on Science Education Standards and Assessment, National Research Council.. (1995). National Science Education Standards, First Printing. Washington, D.C.: National Academies Press. Retrieved April 4, 2001, from http://www.nap.edu/readingroom/books/nses/html/ 